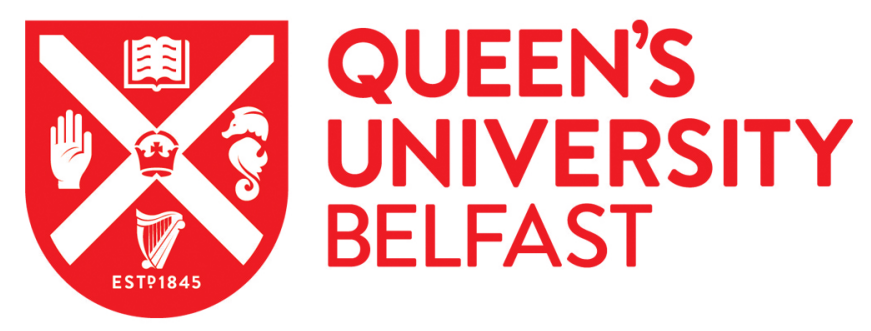

\title{
Effect of Impeller Design on Homogeneity, Size and Strength of Pharmaceutical Granules produced by High Shear Wet Granulation
}

Mirza, Z., Liu, J., Glocheux, Y., Albadarin, A. B., Walker, G. M., \& Mangwandi, C. (2015). Effect of Impeller Design on Homogeneity, Size and Strength of Pharmaceutical Granules produced by High Shear Wet Granulation. Particuology, 23, 31-39. https://doi.org/10.1016/j.partic.2014.12.009

Published in:

Particuology

Document Version:

Peer reviewed version

Queen's University Belfast - Research Portal:

Link to publication record in Queen's University Belfast Research Portal

Publisher rights

(c) 2015 Elsevier Ltd. This manuscript version is made available under the CC-BY-NC-ND 4.0 license http://creativecommons.org/licenses/by$\mathrm{nc}-\mathrm{nd} / 4.0 /$ which permits distribution and reproduction for non-commercial purposes, provided the author and source are cited.

\section{General rights}

Copyright for the publications made accessible via the Queen's University Belfast Research Portal is retained by the author(s) and / or other copyright owners and it is a condition of accessing these publications that users recognise and abide by the legal requirements associated with these rights.

Take down policy

The Research Portal is Queen's institutional repository that provides access to Queen's research output. Every effort has been made to ensure that content in the Research Portal does not infringe any person's rights, or applicable UK laws. If you discover content in the Research Portal that you believe breaches copyright or violates any law, please contact openaccess@qub.ac.uk. 
Ahmad B. Albadarin ${ }^{1,2}$

5

6

7

8

9

University of Limerick, Ireland.

10

11

12

Corresponding author

13

E-mail: c.mangwandi@qub.ac.uk (C.Mangwandi),

14

Tel. $+44(0) 2890974378$

15

Fax. +44 (0) 2890976524 
Design of small mixer impellers is not tailored for granulation as they are intended for a

19 wide range of processes. The Kenwood KM070 was employed as a standard apparatus to undertake this investigation. Five different impeller designs with different shapes and surface areas were used. The aim of this research was to evaluate the performances of these impellers to provide guidance on the selection and design for the purposes of granulation. Lactose granules were produced using wet granulation with water as the binder. The efficacy of respective granulates was measured by adding an optically sensitive tracer. This was used to determine variation of active ingredient across random samples of granules from the same size classes. It was found that impeller design influenced the homogeneity of the granules and therefore can affect final product performance. The variation of active ingredient across granule of different sizes was also investigate. The study shows that small granules were more potent when compared to the larger granules.

\section{KEYWORDS}

31 Granules strength; impeller design; homogeneity; high shear granulation; lactose 32 monohydrate 


\section{INTRODUCTION}

Granulation is a size enlargement unit operation in which granular products are produced by sticking together powdery particles with a binder. It has wide applications in several industries for instance pharmaceuticals, detergent industries, fine chemicals and fertiliser industries. Particle agglomeration in wet granulation improves the bulk properties of the formulation by enhancing the flow properties, reducing the dustiness and also the improving the compression properties. Several studies investigated the effect of granulation parameters in the high shear mixer on product attributes and demonstrated that control of process parameters is necessary to obtain product with the desired attributes (Campbell et al., 2011; Johansson and Alderborn, 2001; Mangwandi et al., 2010; Mangwandi et al., 2012; Mangwandi et al., 2013a; Niklasson et al., 2005; Shiraishi et al., 1994). The final product properties are influenced by the process parameters and formulation attributes. In addition to formulation and process variables there are equipment variables which can influence the properties of the granule. Examples of these variables are the type and shape of the vessel, the presence of a chopper (Chitu et al., 2011) and nozzle.

The main source of energy in high shear granulation is power dissipation by impeller rotation. The main task of the impeller is to agitate the powder particles and ensure that they are always in continuous motion and to ensure collision between binder particle and powder particles. The other purpose of the impeller is to ensure proper mixing of the materials being granulated. Previous work done in mixing of fluid systems has shown that the design of the impeller has a significant effect on the flow of the fluid (Jirout and Rieger, 2011; Kacunic et al., 2012; Khare and Niranjan, 2002; Kumaresan and Joshi, 2006).

There are scant papers in literature discussing the effect of impeller design on the granulation process (Campbell et al., 2011; Knight et al., 2001; Niklasson et al., 2005; Schaefer 
et al., 1993; Smith et al., 2010; Voinovich et al., 1999) . Work done by Schaefer et al. 1993 on the effect of equipment variables on granulation revealed that the impeller blade design affects the shape of the granules formed (Schaefer et al., 1993). Granules that are more spherical were obtained if an impeller with a curved blade was used whilst granulating using a flat blade impeller resulted in formation of irregular shaped granules.

The Kenwood food processer (Kenwood, KM070) which has been used as a lab scale high shear mixture in previous studies (Mangwandi et al., 2013a; Mangwandi et al., 2013b, c) comes with different impellers since it is designed for mixing a range of different materials. Images of the different impeller design are shown in Fig. 1. In the previous studies (Mangwandi et al., 2013a; Mangwandi et al., 2013b, c) only one type of impeller was used, the High Temperature Flexible Beater (HTFB - 14). The aim of this paper is to evaluate the performance of the other impellers in high shear wet granulation in terms of extent of mixing, strength of the granules formed and the size distributions. The extent of mixing will be evaluated using the method used in previous work (Mangwandi et al., 2011; Mangwandi et al., 2014; Mangwandi et al., 2013c).

\section{MATERIALS \& METHOD}

\subsection{Materials}

Lactose monohydrate powder, supplied by Sigma Aldrich GmbH, was used as the main excipient. Methylene Blue (MB) - high purity biological strain, produced and supplied by Sigma Aldrich, was used as a model active ingredient.

\subsection{Binder Preparation and Granulation}


All granulation experiments were performed in a Kenwood processor (KM 70). Six granulation experiments were done in triplicates. The granulation conditions used in all the experiments are summarised in Table 1 . The purpose of experiments 1 and 2 was to check whether addition of methylene blue (MB) to the granulation liquid had any effect on the granulation properties. The same type of impeller was used in these experiments. Experiments 2 to 6 were used to investigate the effect of impeller type on the batch homogeneity, granule mechanical strength and shape. Methylene blue was added to deionised water to produce a MB solution, with a concentration of $20 \mathrm{ppm}$.

\subsection{Material Characterisation}

Data were collected on the powdered samples using a Philips Xpert Pro-Pan-Analytical

diffractometer. The instrument used a monochromated $\mathrm{Cu}$ Ka lamp radiating at lambda value of 1.5406 Armstrong. The samples were housed in a flat plate sample holder and analysed through a $2 \theta$ range of $5-40^{\circ}$, using $0.16713^{\circ}$ steps over a period of 12 minutes. XRD patterns for alpha lactose powder, granulated lactose with water and granulated lactose with watermethylene blue are shown in Fig. 2. No structural change is noticed in lactose; therefore methylene blue can be used as an inert tracer to monitor lactose granulation in water.

\subsection{Granule Drying and Size Analysis}

After granulation each batch of granules was transferred to flat aluminium trays with dimensions 236 mm X 297 mm X 59 mm, ensuring that the granules were evenly spread on the tray surface. The granule trays were then transferred to an oven (Binder FD249, Binder GmbH, Germany) pre-set to a temperature of $60{ }^{\circ} \mathrm{C}$ and dried for 12 hours. After drying the granules

101 were allowed to cool to room temperature and then stored in sealed bags until further needed. sizes used were as follows; 350, 500, 600, 710, 1000, 1180, 1400, 1700, 2000, 2360, 3350, and 
$1044000 \mu \mathrm{m}$. The stack of sieves with the granules was placed on an orbital sample shaker, Stuart

105 Orbital Shaker, supplied by Cole-Parmer UK. The speed of the shaker was set to $180 \mathrm{rpm}$ and

106 the sieving duration to 5 min.

107 The targeted range of granule size in the experiments undertaken was 0.2 to $4 \mathrm{~mm}$ which is

108 the typical size range of pharmaceutical granules (Summers and Aulton, 1988). The percentage

109 of granules in this size range was referred to as the product yield ( $\Psi$ ) and is calculated by the

110 following equation;

111

$$
\Psi=\left(\frac{m_{\text {pro }}}{m_{\text {Bat }}}\right) \times 100 \%
$$

112 where $m_{\text {pro }}$ is the mass of granules in the required size range and $m_{\text {Bat }}$ is the mass of total

113 granules produced in a batch. Granules in the size range 0.5 to $4 \mathrm{~mm}$ were considered to be the

114 product, whilst those below and above this range were considered to be fines and oversize

115 granules respectively.

\subsection{Determination of Homogeneity across granules of same size}

117 Ten random samples of approximately $1 \mathrm{~g}$ of granules in the required size range were

118 withdrawn from each batch. Colloids were prepared from each of the samples by adding the

119 granules to $50 \mathrm{ml}$ of de-ionised water. The concentration of the methylene blue solution was

120 obtained by measuring the absorbance of the solution at a single wavelength of $664 \mathrm{~nm}$ and

121 calculating the concentration from the previously determined calibration equation. The

122 uniformity coefficient was calculated using the following equation (Mangwandi et al., 2011;

123 Mangwandi et al., 2013c; Mangwandi et al., 2015);

$124 \quad \kappa=\frac{S}{\hat{c}}$

Eq. 2 
125 where $\hat{c}$ is the mean of the samples and $S$ is the standard deviation of methylene blue

126 concentration in the samples;

127

$$
S=\sqrt{\frac{\sum_{i}\left(c_{i}-\hat{c}\right)^{2}}{n-1}}
$$

128 In Eq. (3) above, $n$, is the total number of samples analysed and $c_{i}$ is the MB concentration in

129 the $i^{\text {th }}$ sample.

130 MB concentration in granules for each particle size of granules was analysed in the same

131 way and the concentration distribution in function of the particles sizes were plotted.

132 The homogeneity coefficient can then be defined as;

$$
\eta=1-\kappa
$$

Eq. 4

134 where $\kappa$ is as define in $E q .2$ and $0 \leq \eta \leq 1$. A value of homogeneity coefficient of 1 is assigned

135 to a completely homogeneous distribution of the pseudo active ingredient while a low value of

$136 \eta$ indicates poor distribution.

\section{$137 \quad$ 2.6 Methylene Blue distribution across different size classes}

138 The distribution of the MB across different size of the granules was measured by dissolving

139 a known mass of granules in a known volume of distilled water and measuring the absorbance

140 of the colloid at a wavelength of $664 \mathrm{~nm}$ using a spectrophotometer. The concentration (in

$141 \mathrm{ppm}$ ) of the colloid was calculated using Eq. 5. The concentration of the MB in dry sample

142 (mg/g) was then determined from; 
where $m_{M B}$ is the mass of MB added to the batch; $m_{p}$ is total mass of powder (mass of lactose and MB added; $m_{s}\left(x_{i}\right)$ mass of sample granules from size class $x_{i}$ used in measurement; $V$ (in litres) is the volume of dissolution medium.

\subsection{Granules Strength Analysis}

The strength of granules in the size range 2000 to $2360 \mu \mathrm{m}$ was determined from diametric compression of the single granules using the method described previously (Mangwandi et al., 2010; Mangwandi et al., 2007). Eq. 6 was used to determine the granule strength from the failure load, $F_{f}$, and the granule diameter, $D$, which is measured as the distance between the fixed platen and the movable platen, when first contact is made between the granule

153 (Hiramatsu and Oka, 1966);

$154 \quad \sigma=2.8 \times\left(\frac{F_{f}}{\pi D^{2}}\right)$ Eq. 6

\subsection{Shape Analysis}

The shape of the granules from different batches was analysed using an Eyecon 3D particle imager (Innopharmalabs, Ireland). The Eyecon device is able to measure particles size from 50$3000 \mu \mathrm{m}$. The device applies blue, green, and red light to the analysed objects and several images are generated. Irregular particle shapes are mapped by the software and several measurements are logged. The characteristics of the granule size distribution; $d_{10}, d_{50}, d_{90}, d_{\max }$

$161, \mathrm{~d}_{\min }$ and, aspect ratio are presented in report form at the end of the measurement. The particle 162 size measurements are taken directly from the image analysis and there is no model applied to 163 the data. 


\section{RESULTS \& DISCUSSION}

165

166

167

168

171

172

173

174

$176 \quad \bar{d}=\frac{\sum_{i=1}^{n} m_{i} \bar{x}}{\sum_{i=1}^{n} m_{i}}$

\subsection{Effect of addition of MB}

Preliminary results show that addition of MB to the formulation did not significantly affect the granulation process. The granule size distribution and the strength of formulation with and without MB are shown in Fig. 3 and Table 1 respectively. The results are to be expected considering the low level of concentration of the MB used.

\subsection{Effect of Impeller Design on Granule size distribution}

The impeller design has an impact on the average granule size and the granule size distributions of the batches. The results are presented in Fig. 4 (a). It is noticeable from this Fig. that for all the batches there was a large percentage of granules bigger than $4000 \mu \mathrm{m}$. The presence of these large granules could be attributed to the higher liquid to solid ratio used in the experiments. The mass mean diameter of the granules was calculated according to:

Eq. 7 where $m_{i}$ is mass of granules in the interval $x_{i}$ to $x_{i+1}$ with an average size of $\bar{x}$.

One Way Repeated measures ANOVA statistical analysis, performed using Sigma Plot V. 11 (Systat Software Inc, USA) on the averages from three measurements for each of the 5 experiments showed that the differences in the average values were greater than would be expected by chance; there is a statistically significant difference $(\mathrm{P}=0.037)$. The distribution of the granules between the three categories i.e. fines, product and coarse granules is shown in Fig. 4 (c). The largest fraction of oversized granules is obtained when the impeller ST-17 is employed. Using this impeller produces negligible amount of fines. It seems that this impeller is ineffective in breaking down the oversized particles. The minimum level of oversized 
186

granules was obtained when the SPPW-15 impeller was used. The highest fraction of product was obtained when the HTFB-14 impeller was used. It must be pointed out that there is no significant difference between the product fractions for the SSPW-15 and the HFTB-14 impellers. There is no statistically significant difference between the product yield values from the batches produced using the SSPW-15 and the HTFB-14 impellers, which is around $40 \%$. The use of the impellers SSKB-13 and ST-17 result in formation of a larger fraction of the coarse granules which would necessitate inclusion of a size reduction step to convert the oversize product into usable product.

\subsection{Effect on MB content distribution}

Fig. 5 shows variation of the MB concentration in the samples of granules taken from different sizes. It is evident from this figure that the finer granules have a higher concentration compared to larger granules. Granules in the size range 1 to $4 \mathrm{~mm}$ have almost similar MB concentrations for all the cases. This is not always the case when using drug molecules. Different views have been expressed regarding the drug distribution across granules of different sizes. Differences in solubility and particle size differences between the filler and drug material have been cited as reasons contributing to inhomogeneity (Ojile et al., 1982; Selkirk, 1976). It has also been reported that granulations involving drugs or active ingredients that are finer compared to filler material can result in smaller granules that have higher drug composition compared to the other granules (Egermann and Reiss, 1988). However this could not be used to explain the distribution of MB shown in Fig. 5 because MB was added to the binder solution form during granulation. Previous work has also shown that larger granules have higher binder content compared to the smaller granules (Scott et al., 2000). Therefore one can expect larger granules to have higher composition of $\mathrm{MB}$, since they should contain more binder. It can also be observed from Fig. 5 that the batches produced by HTFB-14 impeller had 
the least variation in the MB concentration across all sizes whilst that produced by ST-17 exhibited the largest variation.

The homogeneity coefficient based on samples taken from all sizes was determined to compare the efficacy of mixing by the different impellers; the results are presented in Fig. 6 . It is apparent from this figure that HTFB-14 had the largest value of homogeneity coefficient implying that better mixing was achieve using this impeller. ST-17 impeller produced batches which showed the greatest inhomogeneity. This is also supported by the observation that the same batch had the highest presence of oversized granules.

\subsection{Effect of impeller design on granule homogeneity}

The homogeneity of the granules from the 5 experiments were analysed for three difference size ranges; $710-1000 \mu \mathrm{m}, 1000$ to $1180 \mu \mathrm{m}$ and 3350 to $4000 \mu \mathrm{m}$ in accordance to the method described in section 2.3. The results are presented in Fig. 7 (a). For the granules in the size range 710 to $1000 \mu \mathrm{m}$, the concentration of $\mathrm{MB}$ is in the range 0.4 to $0.85 \mathrm{ppm}$. The highest concentration of granules for this case was obtained when using the impeller HFTB-14. The MB concentration of granules in this range was similar for the impellers SSKB-13 and the SSPW-15. Granules obtained using the ST-17 impeller had the least concentration of MB. For the next size class investigated, 1000 to $1180 \mu \mathrm{m}$, the concentration of MB ranges from 0.52 to $0.64 \mathrm{ppm}$. The variability of the MB concentration for this size range across the batches was 228 lower than that for the 710 to $1000 \mu \mathrm{m}$ size class. The greatest variability in concentration of 229 the MB in the granules across batches was observed for the larger granules (3350 to $4000 \mu \mathrm{m}$ ).

$$
\bar{C}_{i, \text { theo }}=\frac{m_{b i n} \tilde{c}_{i, b i n}}{m_{b a t}}
$$


In Eq. (8), $m_{b i n}$ is the expected mass of binder in the granule, $\widetilde{c}_{i, b i n}$ is the MB concentration

234 in the binder, $m_{b a t}$ is the mass of the wet batch of granules and $\mathrm{V}$ is the volume of deionised 235 water used to dissolve $1 \mathrm{~g}$ of granules during the test.

236 Substituting the correct values of the mass of binder used in the granulation experiment (40 237 g) and the concentration of the MB in the binder solution (20 ppm) and mass of each batch $2380.20 \mathrm{~kg}$ gives a theoretical average concentration of $4 \mathrm{ppm}$. It is then clear from Fig. 7(a) that 239 all the granules tested in this study had below average concentration of the MB.

240 For most of the impellers, granules with different sizes have significantly different 241 concentration of MB; for the SSD-16 and SSPW-15 impellers, the MB concentration decreased 242 with increasing granule size. When the ST-17 impeller is used, granules in the size range 710 $2431000 \mu \mathrm{m}$ had similar concentration to those in the $3350 \mu \mathrm{m}$ to $4000 \mu \mathrm{m}$ range. The granules 244 produced by the impeller HTFB-14 had most similar concentrations of MB. This would give 245 the impression that granulating using an impeller would result in better distribution of the MB across granules of different sizes (see the circle in Fig. 7 (a)). There are previous results in 247 literature describing the binder distribution in high shear granulation and showing that larger 248 granules have higher binder content compared to smaller granules (Osborne et al., 2010; 249 Reynolds et al., 2004; Smith et al., 2010). In another article (Ramachandran et al., 2008), it is 250 reported that granules in the mid-range contain the highest amount of binder compared to the 251 small and large granules. Fig. 7(b) shows the uniformity coefficient of the MB in granules of 252 different sizes produced by different impeller design. The Homogeneity coefficient gives an 253 indication of variability of the MB across each size class. The homogeneity is defined in such a 254 way that a higher value of the coefficient indicates greater variability (less homogeneity) whilst 255 a lower value would indicate better homogeneity (less variability). There is variation in the 256 homogeneity coefficient both across granules made from the same impeller (different sizes) 
and also variation across granules of the same size but produced by different impeller. No 258 definite correlation could be identified between the impeller type and the homogeneity coefficient. For the SSKB-13, HTFB-14 and SHD impellers the results show that the homogeneity coefficient is lower for the larger granules compared to the smaller granules. This would imply that there is larger variation in the concentration of MB in the samples taken from larger granules. For the other two impellers the highest value of homogeneity coefficient is obtained from samples of granules of intermediate size.

\subsection{Effect of Impeller Design on Granule Strength}

Statistical analysis of the five groups of strength data (one from each of the impellers) using Kruskal-Wallis One Way ANOVA analysis showed that differences in the median values among the treatment groups was higher than would be expected from chance; there is a statistical significant difference $(\mathrm{P}=0.004)$. This implies that the different impellers produced granules of different strength. However, All Pairwise comparison between the five groups of granules showed that strength data from the SPPW-15 impeller was significantly different form the other four impellers; differences between the other groups was less significant. Summary of the ANOVA analysis results is shown in Fig. 8.

The strength distribution curves of granules produced from the different impeller designs are shown in Fig. 9. It is evident from the figure that the granules from the batch produced by impeller SSPW-15 differed significantly from the rest of the batches and this impeller 276 produced the strongest granules. The variation in the strength results was highest when the SSKB-13 impeller was used and the least variation was obtained when the HFTB impeller was used. Fig. 9 (b) also shows that the largest scatter in the strength data was for granules produced by the impeller SSKB-13. 


\subsection{Effect of Impeller Design on granule shape}

The images shown in Fig. 10 are of granules in the size range $1000-1180 \mu$ m produced by the different types of impeller. It can be noticed from the images that the granules have irregular shape and rough surfaces irrespective of the type of the impeller. For this particular size range and other size ranges investigated 710 - $1000 \mu \mathrm{m} ; 2000-2360 \mu \mathrm{m}$ and 2800 - 3350 $\mu \mathrm{m}$, the impeller design does not seem to have an influence on the shape of the structure of the granules formed. Images of the granules are shown in Fig. 11 This is contrary to earlier work (Schaefer et al., 1993) which reported that impeller design has a slight impact on the granule shape.

The shape of the granules was analysed from images, using the aspect ratio as an indicator of sphericity. The closer the value of the aspect ratio to 1 the less elongated the particle; the further the value from 1 , the more elongated is the particle. The average shape factors of granules from different size ranges produced by different impeller are presented in Fig. 12.

It is quite clear from Fig. 12 that, for the granule in the size range $710-1000 \mu \mathrm{m}$, the type of impeller has no influence on the aspect ratio of the granules. The granules in the size ranges $710-1000 \mu \mathrm{m}$ and 1000 - $1180 \mu \mathrm{m}$ have similar average aspect ratios. The average values of aspect ratio for the granules in the 2360 - $3350 \mu \mathrm{m}$ range are higher than those of the smaller granules for all five groups of granules. For all impeller designs, the smaller granules are less elongated than the larger granules.

The effect of the impeller design on granule attributes is summarised in Table 2. The impellers are ranked from 5 to 1, 5 being the best based on maximising that particular granule attribute. It shows which of the impellers to choose if the aim is to maximise the listed attribute. For instance, for maximum granule strength, the SSPW-15 is the one to choose. In terms of better product yield there are two candidates, SSPW-15 and HTFB-14, since the 
product yield from these two do not differ significantly. Overall the HTFB impeller has a highest score compared to the other impellers.

\section{CONCLUSIONS}

It has been shown that the choice of the impeller has an influence on granule size distribution, the granule mean size, and the strength and extent of mixing during granulation. In terms of homogeneity of the pseudo active ingredient, the HTFB impeller outperformed the other impellers. The impeller type does not seem to have a significant influence on the shape of granules formed. For the size range investigated in this work, granules of the highest strength were produced when impeller SSPW-15 was employed whereas the highest granule mean size was obtained with the ST-17. Whilst the different impeller designs performed differently depending which granule property one is looking at, the HTFB-14 seems to be the one to choose if one is looking for an impeller that gives better mixing, good product yield and reasonable granule strength.

\section{REFERENCES}

CAMPBELL, G.A., CLANCY, D.J., ZHANG, J.X., GUPTA, M.K., OH, C.K., 2011. CLOSING THE GAP IN SERIES SCALE UP OF HIGH SHEAR WET GRANULATION PROCESS USING IMPELLER POWER AND BLADE DESIGN. POWDER TECHNOLOGY 205, 184-192.

CHITU, T.M., OULAHNA, D., HEMATI, M., 2011. WET GRANULATION IN LABORATORY-SCALE HIGH SHEAR MIXERS: EFFECT OF CHOPPER PRESENCE, DESIGN AND IMPELLER SPEED. POWDER TECHNOLOGY 206, 3443.

EGERMANN, H., REISS, W., 1988. EFFECT OF PARTICLE SIZE OF DRUG AND DILUENT ON DRUG DISTRIBUTION IN GRANULE SIZE FRACTIONS. ACTA PHARMACEUTICAL TECHNOLOGY 34, 5S. 
INTERNATIONAL JOURNAL OF ROCK MECHANICS AND MINING SOCIETY 3, 89-99.

JIROUT, T., RIEGER, F., 2011. IMPELLER DESIGN FOR MIXING OF SUSPENSIONS. CHEMICAL ENGINEERING RESEARCH AND DESIGN 89, 11441151.

JOHANSSON, B., ALDERBORN, G., 2001. THE EFFECT OF SHAPE AND POROSITY ON THE COMPRESSION BEHAVIOUR AND TABLET FORMING ABILITY OF GRANULAR MATERIALS FORMED FROM MICROCRYSTALLINE CELLULOSE. EUROPEAN JOURNAL OF PHARMACEUTICS AND BIOPHARMACEUTICS 52, 347-357.

KACUNIC, A., AKRAP, M., KUZMANIC, N., 2012. EFFECT OF IMPELLER TYPE AND POSITION IN A BATCH COOLING CRYSTALLIZER ON THE GROWTH OF BORAX DECAHYDRATE CRYSTALS. CHEMICAL ENGINEERING RESEARCH AND DESIGN 91, 274-285.

KHARE, A.S., NIRANJAN, K., 2002. THE EFFECT OF IMPELLER DESIGN ON GAS HOLD-UP IN SURFACTANT CONTAINING HIGHLY VISCOUS NON-NEWTONIAN AGITATED LIQUIDS. CHEMICAL ENGINEERING AND PROCESSING: PROCESS INTENSIFICATION 41, 239-249.

KNIGHT, P.C., SEVILLE, J.P.K., WELLM, A.B., INSTONE, T., 2001. PREDICTION OF IMPELLER TORQUE IN HIGH SHEAR POWDER MIXERS. CHEMICAL ENGINEERING SCIENCE 56, 4457-4471.

KUMARESAN, T., JOSHI, J.B., 2006. EFFECT OF IMPELLER DESIGN ON THE FLOW PATTERN AND MIXING IN STIRRED TANKS. CHEMICAL ENGINEERING JOURNAL 115, 173-193.

MANGWANDI, C., ADAMS, M.J., HOUNSLOW, M.J., SALMAN, A.D., 2010. EFFECT OF IMPELLER SPEED ON MECHANICAL AND DISSOLUTION PROPERTIES OF HIGH-SHEAR GRANULES. CHEMICAL ENGINEERING JOURNAL 164, 305-315.

MANGWANDI, C., ADAMS, M.J., HOUNSLOW, M.J., SALMAN, A.D., 2011. EFFECT OF BATCH SIZE ON MECHANICAL PROPERTIES OF GRANULES IN HIGH SHEAR GRANULATION. POWDER TECHNOLOGY 206, 44-52.

MANGWANDI, C., ADAMS, M.J., HOUNSLOW, M.J., SALMAN, A.D., 2012. AN INVESTIGATION OF THE INFLUENCE OF PROCESS AND FORMULATION VARIABLES ON MECHANICAL PROPERTIES OF HIGH SHEAR GRANULES USING DESIGN OF EXPERIMENT. INTERNATIONAL JOURNAL OF PHARMACEUTICS 427, 328-336.

MANGWANDI, C., ADAMS, M.J., HOUNSLOW, M.J., SALMAN, A.D., 2014. INFLUENCE OF FILL FACTOR VARIATION IN HIGH SHEAR GRANULATION 
ON THE POST GRANULATION PROCESSES: COMPRESSION AND TABLET PROPERTIES. POWDER TECHNOLOGY 263, 135-141.

MANGWANDI, C., ALBADARIN, A.B., AL-MUHTASEB, A.A.H., ALLEN, S.J., WALKER, G.M., 2013A. OPTIMISATION OF HIGH SHEAR GRANULATION OF MULTICOMPONENT FERTILISER USING RESPONSE SURFACE METHODOLOGY. POWDER TECHNOLOGY 238, 142-150.

MANGWANDI, C., CHEONG, Y.S., ADAMS, M.J., HOUNSLOW, M.J., SALMAN, A.D., 2007. THE COEFFICIENT OF RESTITUTION OF DIFFERENT REPRESENTATIVE TYPES OF GRANULES. CHEMICAL ENGINEERING SCIENCE 62, 437-450.

MANGWANDI, C., JIANGTAO, L., ALBADARIN, A.B., ALLEN, S.J., WALKER, G.M., 2013B. ALTERNATIVE METHOD FOR PRODUCING ORGANIC FERTILISER FROM ANAEROBIC DIGESTION LIQUOR AND LIMESTONE POWDER: HIGH SHEAR WET GRANULATION. POWDER TECHNOLOGY 233, 245-254.

MANGWANDI, C., JIANGTAO, L., ALBADARIN, A.B., ALLEN, S.J., WALKER, G.M., 2013C. THE VARIABILITY IN NUTRIENT COMPOSITION OF ANAEROBIC DIGESTATE GRANULES PRODUCED FROM HIGH SHEAR GRANULATION. WASTE MANAGEMENT 33, 33-42.

MANGWANDI, C., ZAINAL, N.A., JIANGTAO, L., GLOCHEUX, Y., ALBADARIN, A.B., 2015. INVESTIGATION OF INFLUENCE OF PROCESS VARIABLES ON MECHANICAL STRENGTH, SIZE AND HOMOGENEITY OF PHARMACEUTICAL GRANULES PRODUCED BY FLUIDISED HOT MELT GRANULATION. POWDER TECHNOLOGY 272, 173-180.

NIKLASSON, B.I., JANSSON, A., KARLSSON, M., FOLESTAD, S., RASMUSON, A., 2005. EMPIRICAL TO MECHANISTIC MODELLING IN HIGH SHEAR GRANULATION. CHEMICAL ENGINEERING SCIENCE 60, 3795-3803.

OJILE, J.E., MACFARLANE, C.B., SELKIRK, A.B., 1982. DRUG DISTRIBUTION DURING MASSING AND ITS EFFECT ON DOSE UNIFORMITY IN GRANULES. INTERNATIONAL JOURNAL OF PHARMACEUTICS 10, 99-107.

OSBORNE, J.D., SOCHON, R.P.J., CARTWRIGHT, J.J., DOUGHTY, D.G., HOUNSLOW, M.J., SALMAN, A.D., 2010. BINDER ADDITION METHODS AND BINDER DISTRIBUTION IN HIGH SHEAR AND FLUIDISED BED GRANULATION. CHEMICAL ENGINEERING RESEARCH AND DESIGN 89, 553-559.

RAMACHANDRAN, R., POON, J.M.H., SANDERS, C.F.W., GLASER, T., IMMANUEL, C.D., DOYLE III, F.J., LITSTER, J.D., STEPANEK, F., WANG, F.-Y., CAMERON, I.T., 2008. EXPERIMENTAL STUDIES ON DISTRIBUTIONS OF GRANULE SIZE, BINDER CONTENT AND POROSITY IN BATCH DRUM 
GRANULATION: INFERENCES ON PROCESS MODELLING REQUIREMENTS AND PROCESS SENSITIVITIES. POWDER TECHNOLOGY 188, 89-101.

REYNOLDS, G.K., BIGGS, C.A., SALMAN, A.D., HOUNSLOW, M.J., 2004. NONUNIFORMITY OF BINDER DISTRIBUTION IN HIGH-SHEAR GRANULATION. POWDER TECHNOLOGY 140, 203-208.

SCHAEFER, T., TAAGEGAARD, B., THOMSEN, L.J., GJELSTRUP KRISTENSEN, H., 1993. MELT PELLETIZATION IN A HIGH SHEAR MIXER. V. EFFECTS OF APPARATUS VARIABLES. EUROPEAN JOURNAL OF PHARMACEUTICAL SCIENCES 1, 133-141.

SCOTT, A.C., HOUNSLOW, M.J., INSTONE, T., 2000. DIRECT EVIDENCE OF HETEROGENEITY DURING HIGH-SHEAR GRANULATION. POWDER TECHNOLOGY 113, 205-213.

SELKIRK, A.B., 1976. THE EFFECT OF SOLUTE MIGRATION ON THE DISTRIBUTION OF BORAX THROUGHOUT A BATCH OF GRANULES. JOURNAL OF PHARMACY AND PHARMACOLOGY 28, 512-514.

SHIRAISHI, T., KONDO, S., YUASA, H., KANAYA, Y., 1994. STUDIES ON THE GRANULATION PROCESS OF GRANULES FOR TABLETING WITH A HIGH SPEED MIXED. I. PHYSICAL PROPERTIES OF GRANULES FOR TABLETING. CHEMICAL AND PHARMACEUTICAL BULLETIN 42, 932-936.

SMITH, R.M., LIU, L.X., LITSTER, J.D., 2010. BREAKAGE OF DROP NUCLEATED GRANULES IN A BREAKAGE ONLY HIGH SHEAR MIXER. CHEMICAL ENGINEERING SCIENCE 65, 5651-5657.

SUMMERS, M., AULTON, M.E., 1988. GRANULATION, IN: AULTON, M.E. (ED.), PHARMACEUTICS: THE SCIENCE OF DOSAGE FORM DESIGN, 7TH ED. CHURCHILL LIVINGSTONE.

VOINOVICH, D., CAMPISI, B., MONEGHINI, M., VINCENZI, C., PHAN-TAN-LUU, R., 1999. SCREENING OF HIGH SHEAR MIXER MELT GRANULATION PROCESS VARIABLES USING AN ASYMMETRICAL FACTORIAL DESIGN. INTERNATIONAL JOURNAL OF PHARMACEUTICS 190, 73-81. 


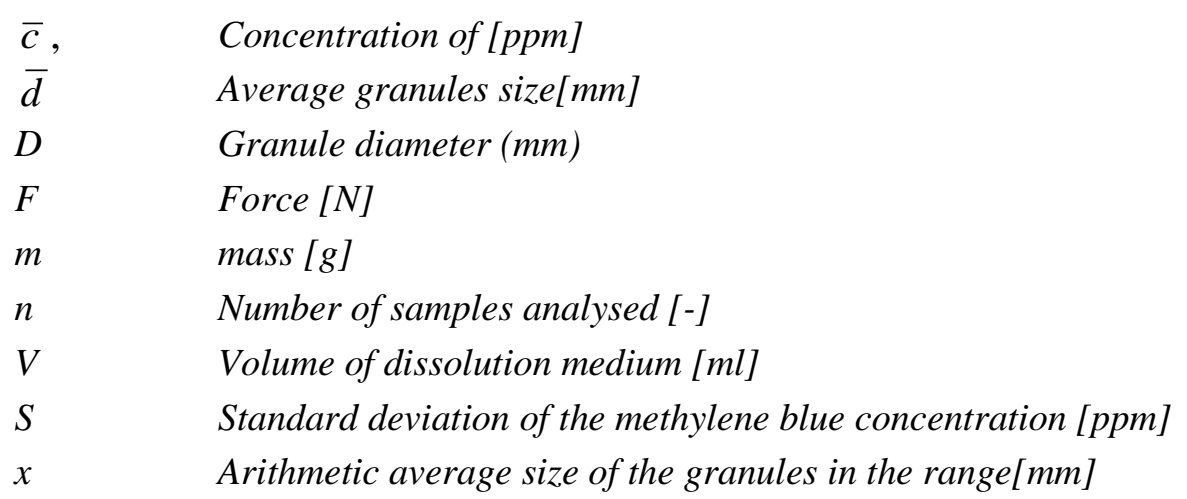

439

\section{$440 \quad$ Greek letters}

441

$\begin{array}{ll}\eta & \text { Homogeneity coefficient [-] } \\ \kappa & \text { Average granules size [mm] } \\ \sigma & \left.\text { Granule strength [Nmm }{ }^{-2} \text { or } \mathrm{MPa}\right] \\ \Psi & \text { Product yield [\%] }\end{array}$

\section{Subscripts}

$\begin{array}{ll}\text { bat } & \text { batch } \\ \text { bin } & \text { binder } \\ \text { exp } & \text { Experimental value } \\ f & \text { failure } \\ i & \text { Sample index } \\ \text { MB } & \text { Methylene blue } \\ p & \text { powder } \\ \text { pro } & \text { product } \\ s & \text { sample } \\ \text { theo } & \text { Theoretical value }\end{array}$

\section{Abbreviation}

$\begin{array}{ll}\text { API } & \text { Active Pharmaceutical } \\ \text { HTFB } & \text { High Temperature Flexible Beater } \\ \text { MB } & \text { Methylene blue } \\ \text { SDH } & \text { Spiral Dough Hook } \\ \text { SSKB } & \text { Stainless Steel K Beater } \\ \text { SSPW } & \text { Stainless Steel Power Whisk } \\ \text { ST } & \text { Stirring Tool } \\ \text { XRD } & \text { X Ray Diffraction }\end{array}$


Table 1: Summary of process and granulation parameters.

\begin{tabular}{ccccccc}
\hline $\begin{array}{c}\text { Experiment } \\
\text { No. }\end{array}$ & $\begin{array}{c}\text { Impeller } \\
\text { type }\end{array}$ & $\begin{array}{c}\text { Impeller } \\
\text { speed } \\
(\mathrm{rpm})\end{array}$ & $\begin{array}{c}\text { Granulation } \\
\text { Time (min) }\end{array}$ & $\begin{array}{c}\text { Mass of } \\
\text { lactose } \\
\text { Powder }\end{array}$ & Binder & $\begin{array}{c}\text { Liquid to } \\
\text { solid Ratio }\end{array}$ \\
\hline 1 & HTFB-14 & 160 & 4 & 200 & water & 0.2 \\
2 & HTFB-14 & 160 & 4 & 200 & Water + MB & 0.2 \\
3 & SSKB-13 & 160 & 4 & 200 & Water + MB & 0.2 \\
4 & SSPW-15 & 160 & 4 & 200 & Water + MB & 0.2 \\
5 & SDH-16 & 160 & 4 & 200 & Water + MB & 0.2 \\
6 & ST-17 & 160 & 4 & 200 & Water + MB & 0.2 \\
\hline
\end{tabular}


449 Table 2: Comparison of the strength of granules produced from different binders. N.B. Errors indicate 450 Standard error in the mean

\begin{tabular}{lcc}
\hline Binder & Impeller & Granule \\
Type & Strength (MPa) \\
\hline Water & HTFB-14 & $0.60 \pm 0.06$ \\
Water + MB & HTFB-14 & $0.65 \pm 0.08$ \\
\hline
\end{tabular}

451

452

453 
454 Table 3: Summary of effect of impeller design on granule attributes.

\begin{tabular}{ccccc}
\hline $\begin{array}{c}\text { Impeller } \\
\text { type }\end{array}$ & $\begin{array}{c}\text { Product } \\
\text { Yield }\end{array}$ & Homogeneity & $\begin{array}{c}\text { Granule } \\
\text { Strength }\end{array}$ & $\begin{array}{c}\text { Granule } \\
\text { Mean Size }\end{array}$ \\
\hline SSKB-13 & 2 & 2 & 2 & 4 \\
HTFB-14 & 5 & 5 & 3 & 2 \\
SSPW-15 & 4 & 4 & 5 & 1 \\
SDH-16 & 3 & 3 & 4 & 3 \\
ST-17 & 1 & 1 & 1 & 5 \\
\hline
\end{tabular}

455

456 


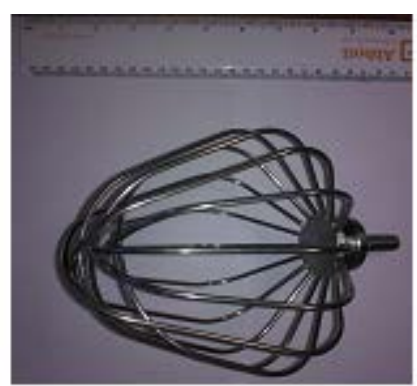

(a)

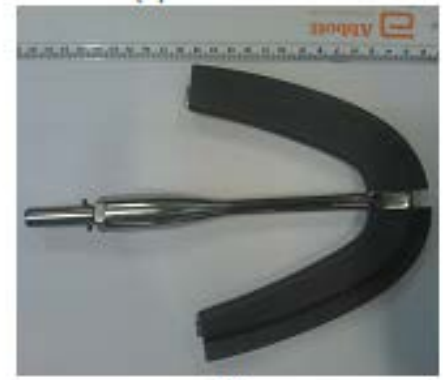

(d)

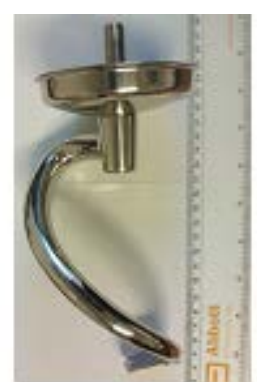

(b)

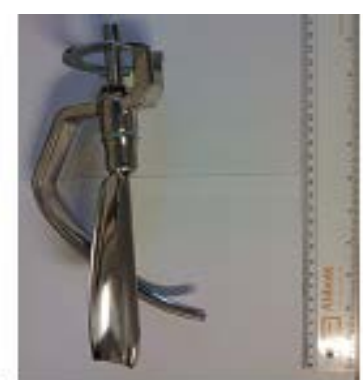

(c)

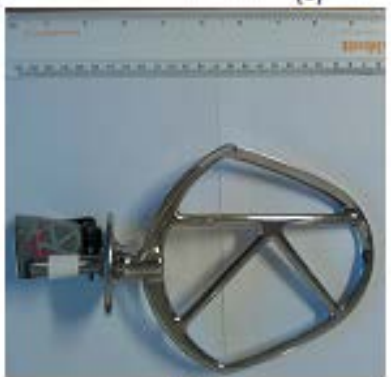

(e)

Fig. 1: Images of the different impeller designs used in the granulation experiments (a) Stainless steel power whisk (SSPW-15) b) Spiral Dough Hook (SDH-16) c )Stirring Tool (ST-17) d) High Temperature Flexible Beater ( HTFB-14) e) Stainless Steel K Beater (SSKB-13) 
463

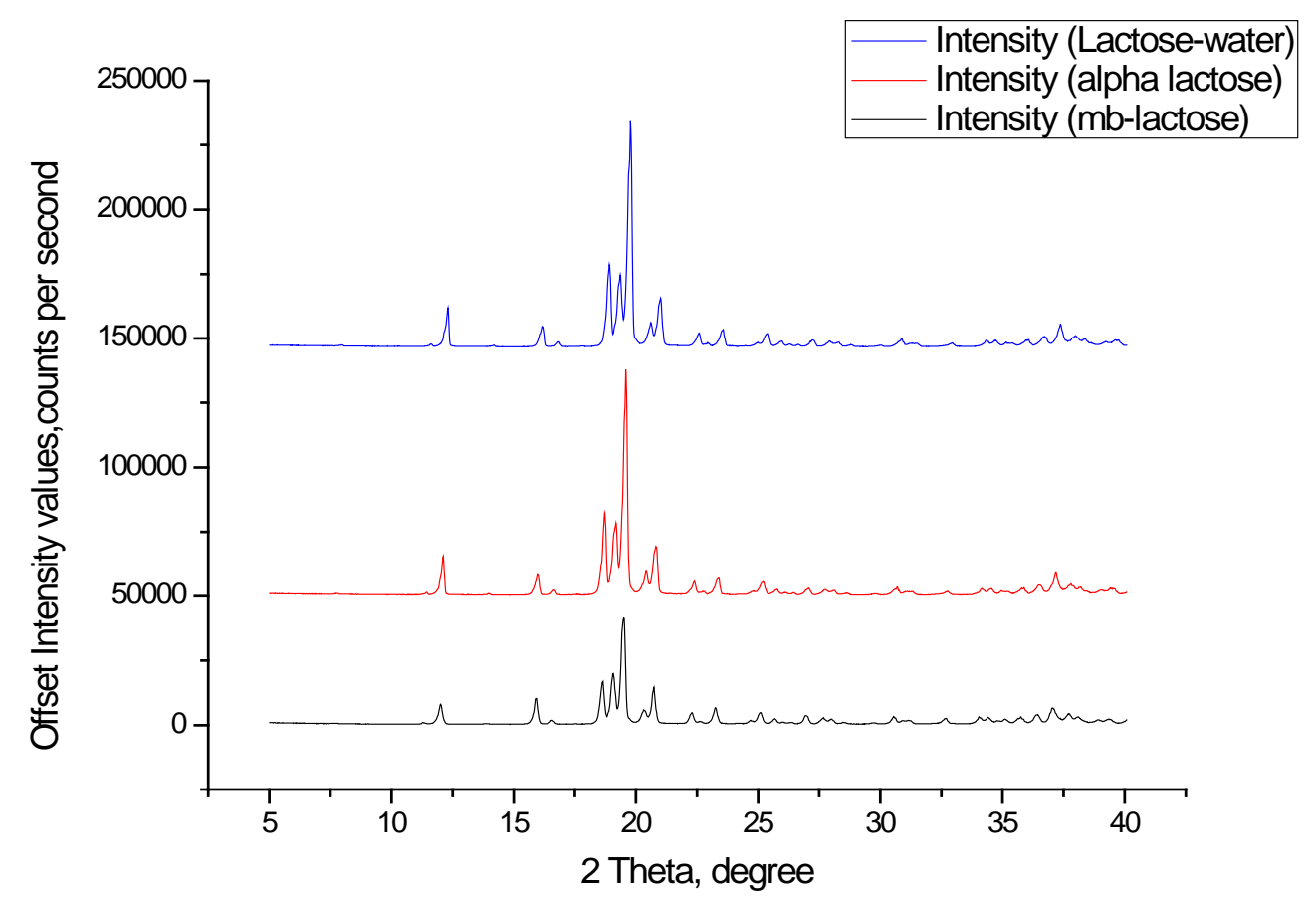

464

465

466

Fig. 2: XRD patterns of samples alpha lactose, granulated lactose from water and water-methylene blue solution.

467

468 


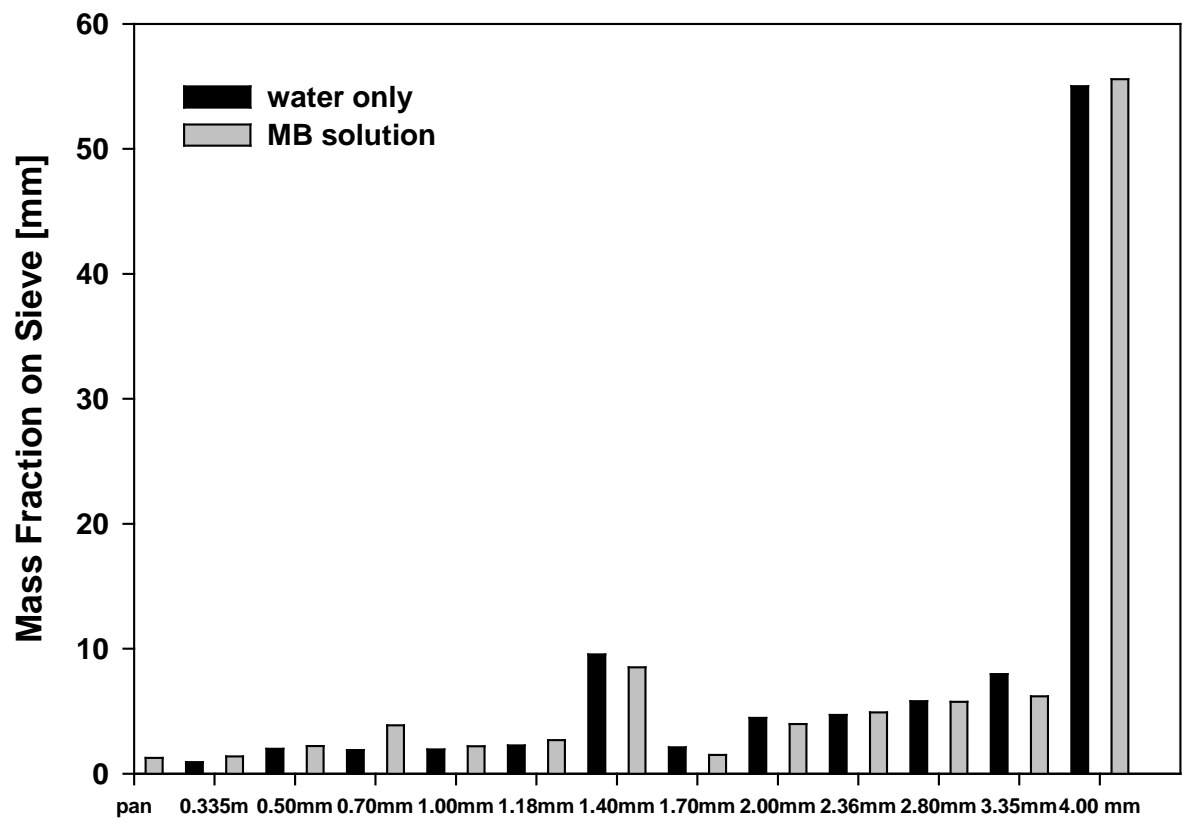

Sieve Size $[\mathrm{mm}]$

Fig. 3: Comparison of size distributions of batch of granules produced using water and MB solution binders. 

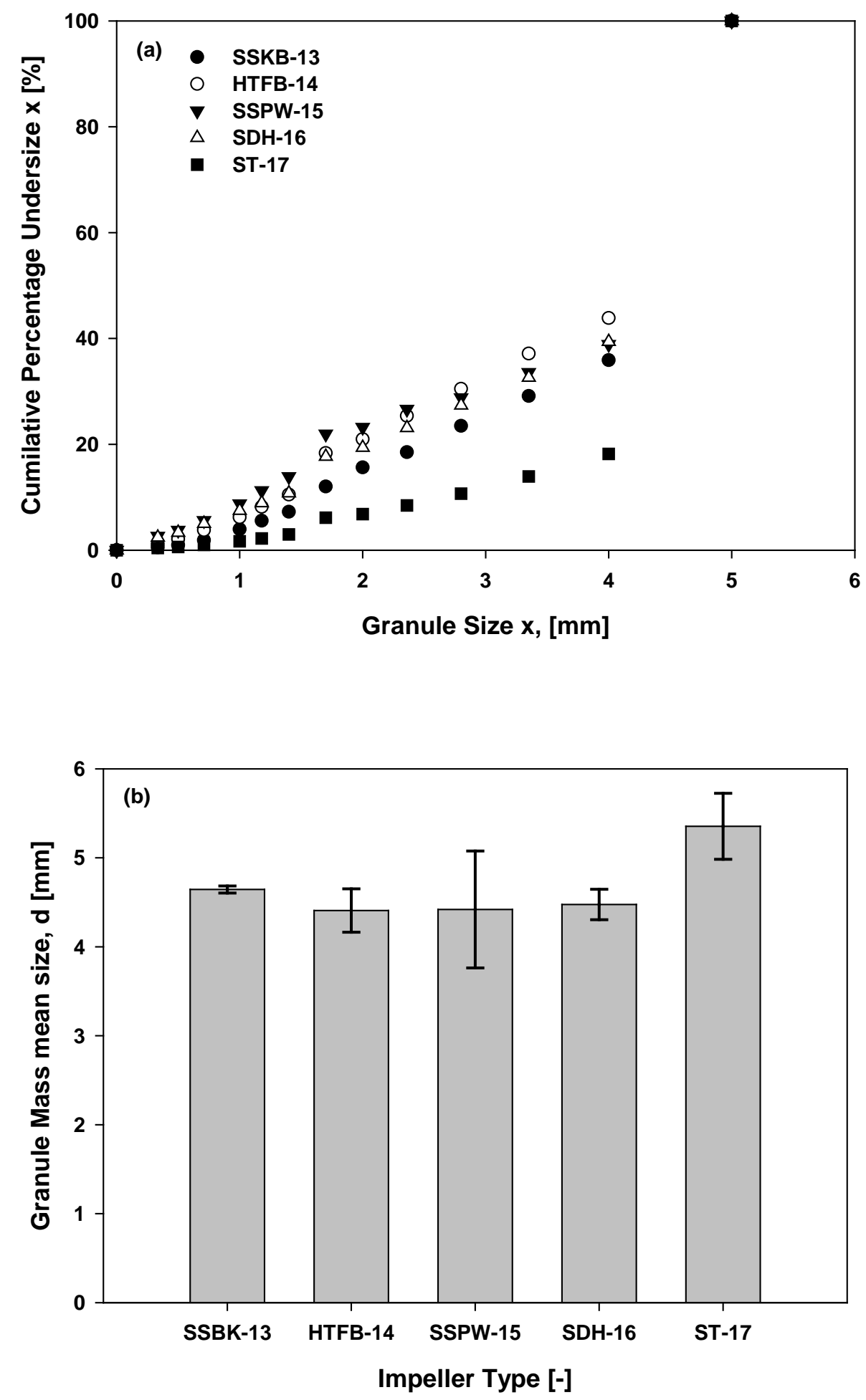


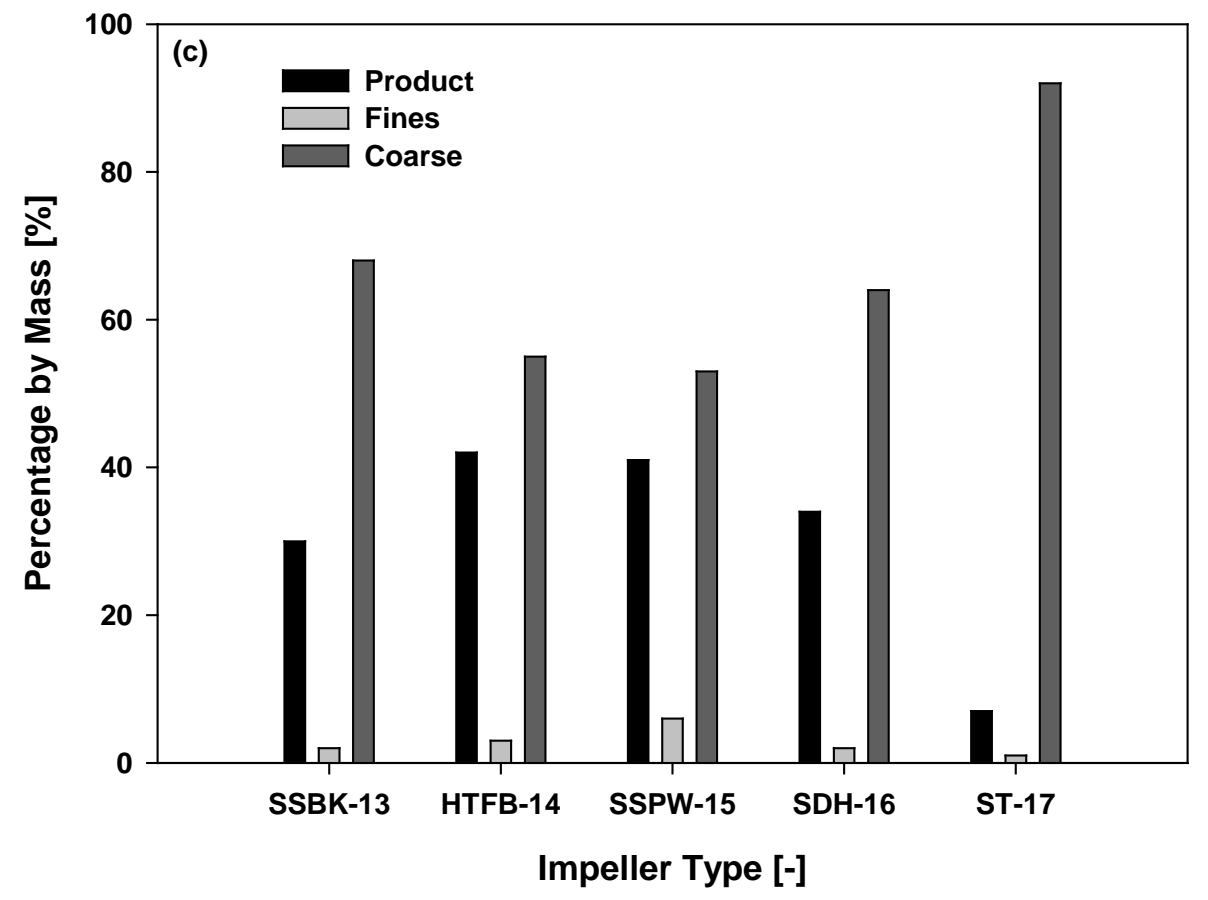

Fig. 4: (a) Typical cumulative granule size distribution plots for experiments 2 to 6. (b) Granule mass mean size as a function of impeller type (c) mass distribution of the granules between fines, product and oversized granules. N.B The plots are average of three replicate experiments. 


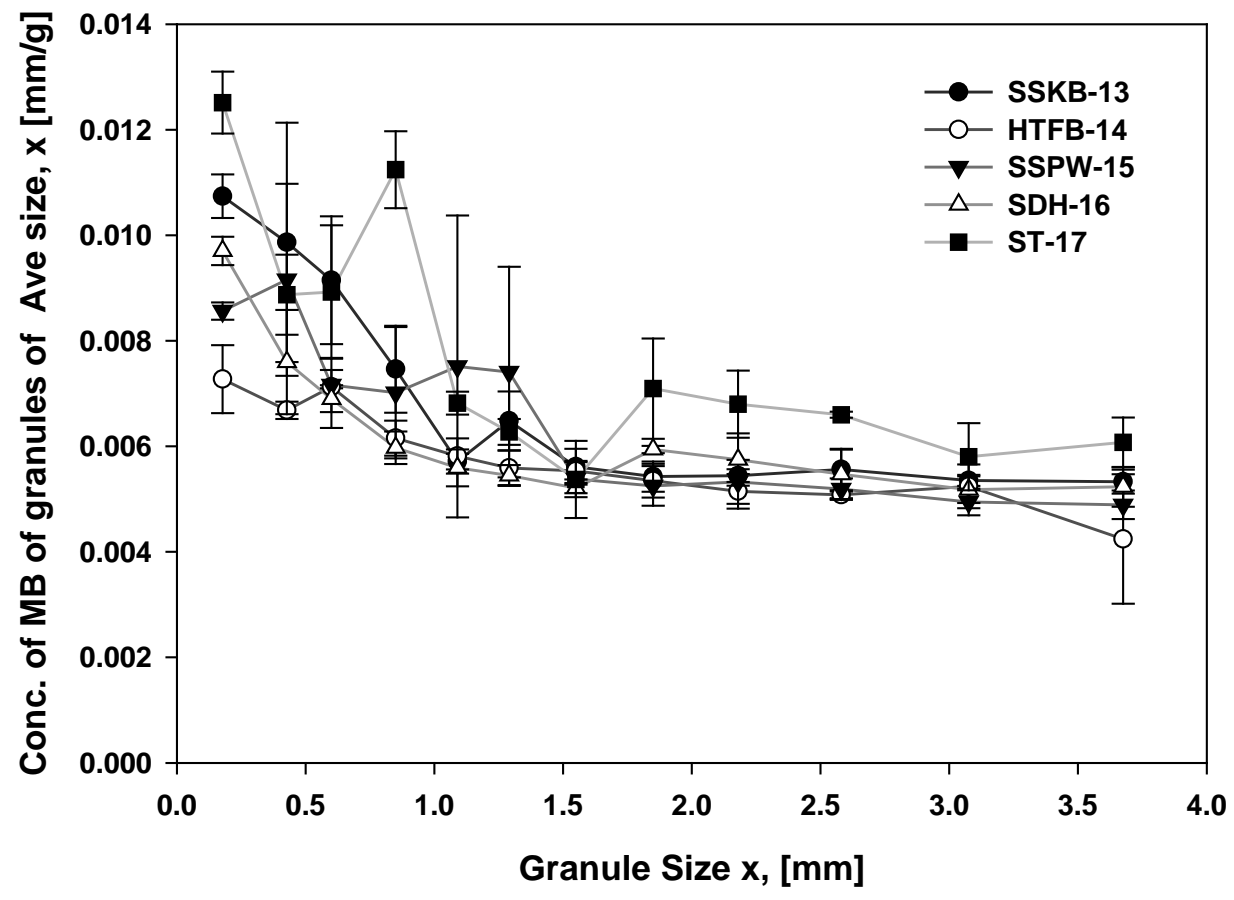

479

Fig. 5: The variation of MB concentration with size class for batches of granules produced with different $480 \quad$ Fig. 5: The va
$481 \quad$ impeller designs.

482 


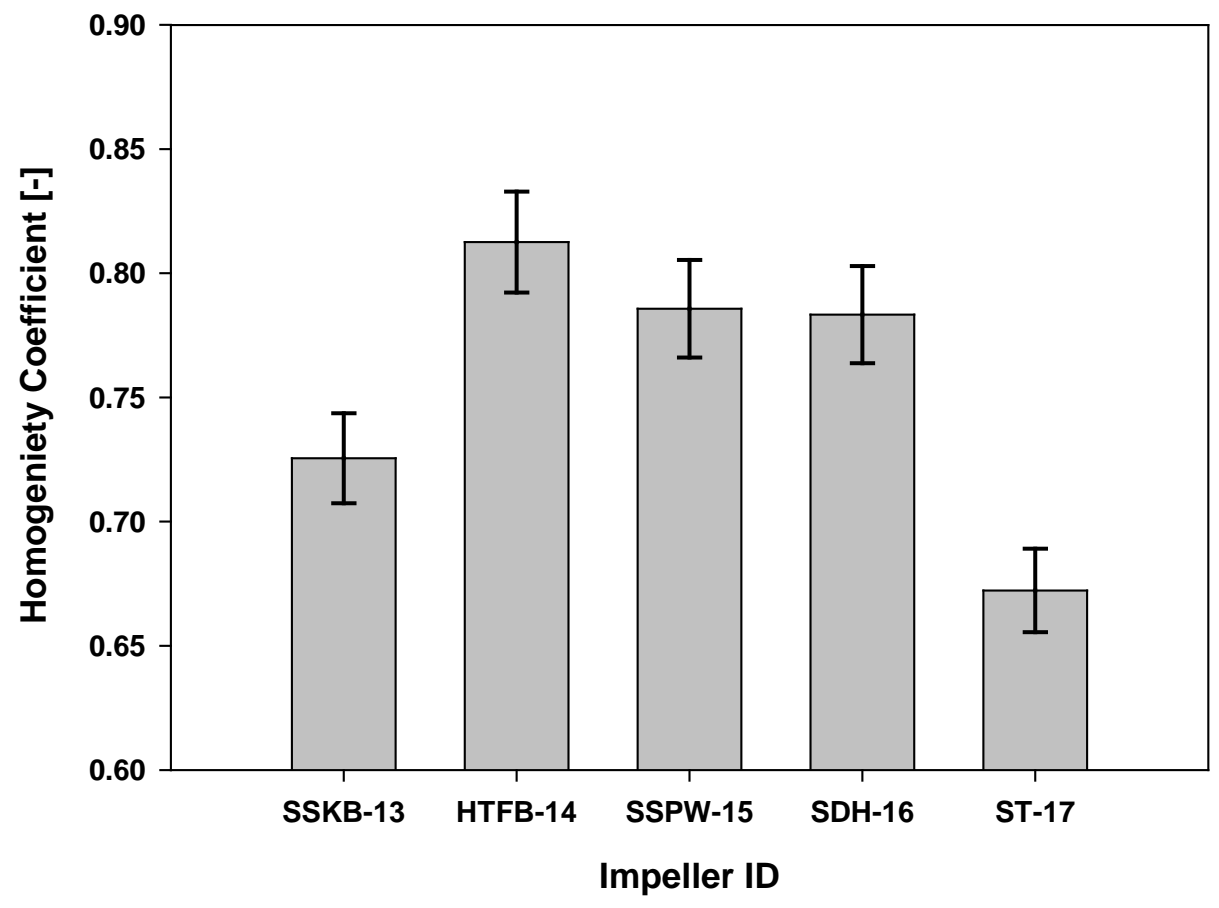

483

Fig. 6: Variation of homogeneity coefficient across different sizes for batches produced with different impellers.

486

487 

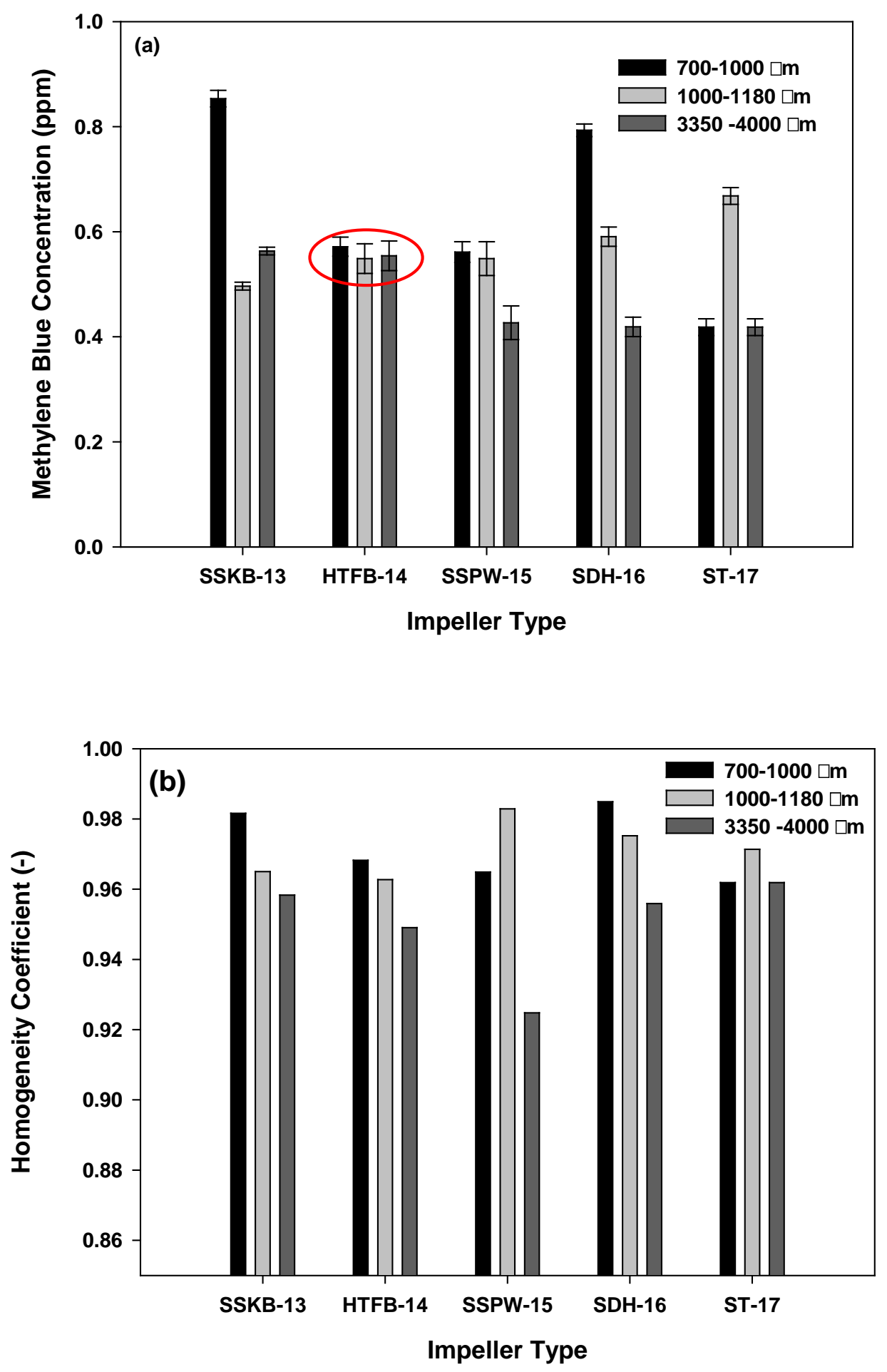

Fig. 7: (a) Methylene blue concentration of granules from different sieve fractions (b) Variation of the granules' homogeneity coefficient with impeller design. 
Data source: Data 2 in Notebook1

$\begin{array}{llcrcc}\text { Group } & \text { N } & \text { Missing } & \text { Median } & \mathbf{2 5} \% & \mathbf{7 5 \%} \\ \text { SSKB-13 } & 25 & 0 & 0.686 & 0.418 & 0.896 \\ \text { HTFB-14 } & 25 & 0 & 0.571 & 0.344 & 0.994 \\ \text { SSPW-15 } & 25 & 0 & 0.998 & 0.679 & 1.563 \\ \text { SDD-16 } & 25 & 0 & 0.621 & 0.350 & 0.870 \\ \text { ST-17 } & 25 & 0 & 0.492 & 0.321 & 0.655\end{array}$

$H=15.242$ with 4 degrees of freedom. $(P=0.004)$

The differences in the median values among the treatment groups are greater than would be expected by chance; there is a statistically significant difference $(P=0.004)$

To isolate the group or groups that differ from the others use a multiple comparison procedure.

All Pairwise Multiple Comparison Procedures (Student-Newman-Keuls Method) :

$\begin{array}{lccr}\text { Comparison } & \text { Diff of Ranks } & \mathbf{q} & \mathbf{P}<\mathbf{0 . 0 5} \\ \text { SSPW-15 vs ST-17 } & 928.000 & 5.123 & \text { Yes } \\ \text { SSPW-15 vs HTFB-14 } & 759.000 & 5.232 & \text { Yes } \\ \text { SSPW-15 vs SDD-16 } & 683.000 & 6.268 & \text { Yes } \\ \text { SSPW-15 vs SSKB-13 } & 620.000 & 8.506 & \text { Yes } \\ \text { SSKB-13 vs ST-17 } & 308.000 & 2.123 & \text { No } \\ \text { SSKB-13 vs HTFB-14 } & 139.000 & 1.276 & \text { Do Not Test } \\ \text { SSKB-13 vs SDD-16 } & 63.000 & 0.864 & \text { Do Not Test } \\ \text { SDD-16 vs ST-17 } & 245.000 & 2.248 & \text { Do Not Test } \\ \text { SDD-16 vs HTFB-14 } & 76.000 & 1.043 & \text { Do Not Test } \\ \text { HTFB-14 vs ST-17 } & 169.000 & 2.319 & \text { Do Not Test }\end{array}$

Fig. 8: Statistical analysis of the granule strength data from batches produce with different impellers. 


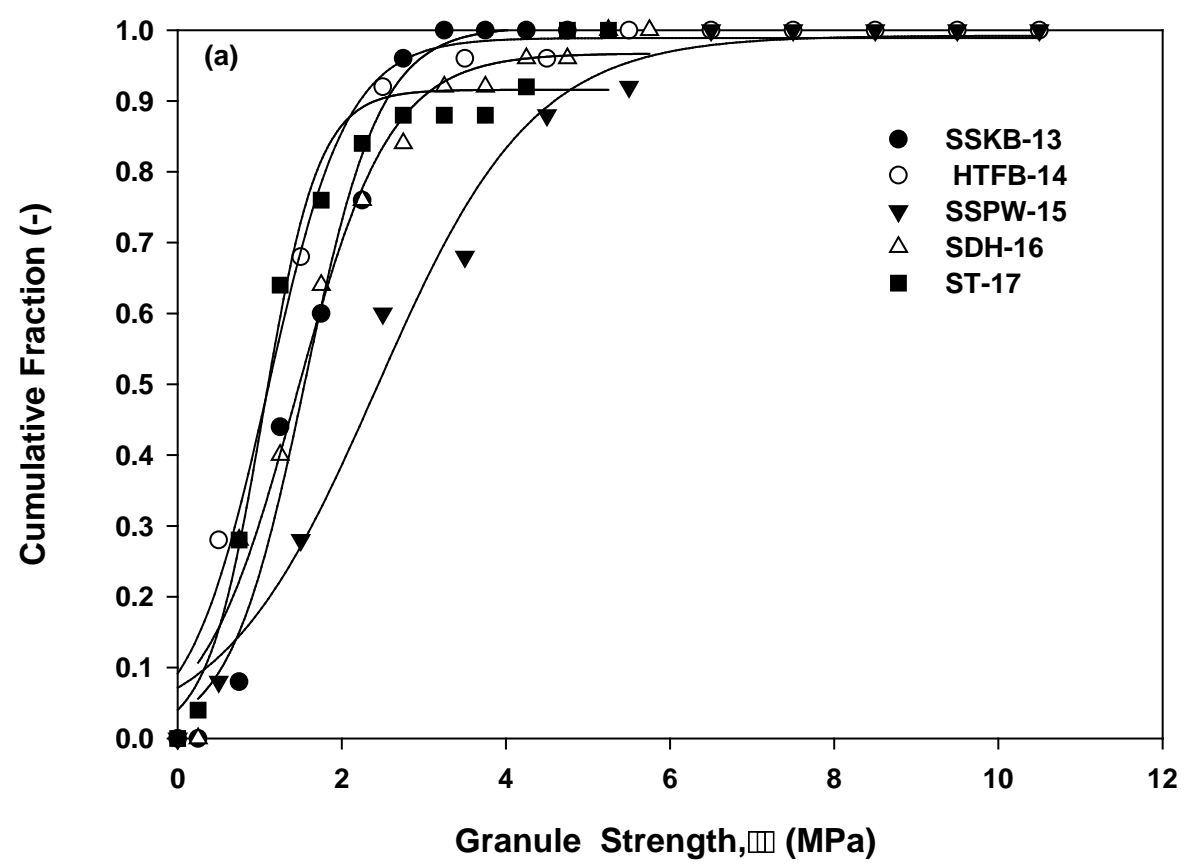

501

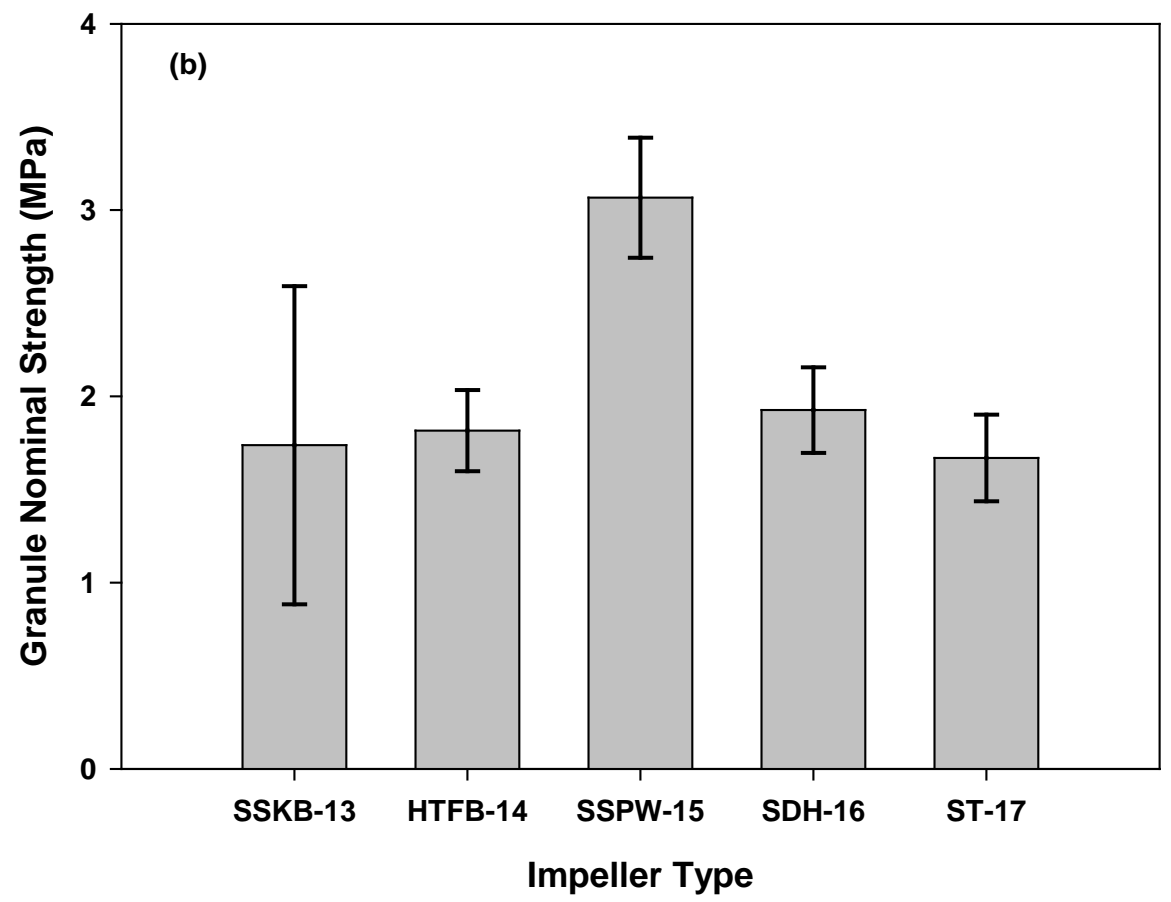

Fig. 9: Effect of impeller type on the strength of the granules. 


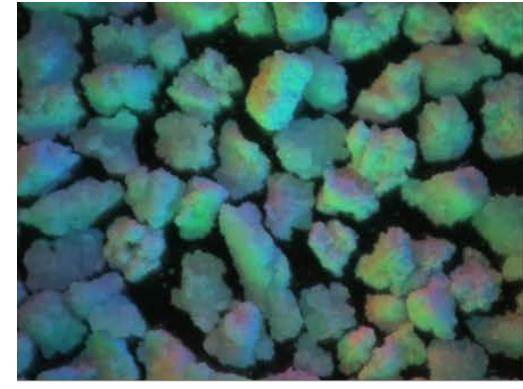

(a) HTFB-13

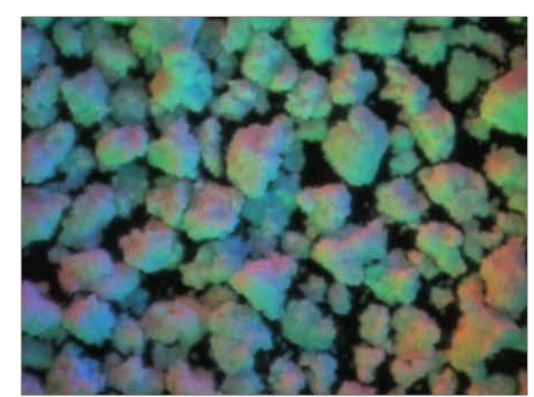

(d)- SDD-16

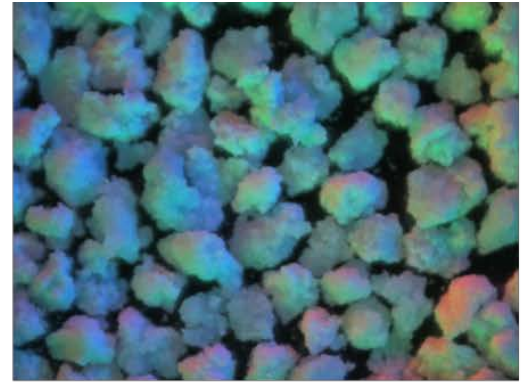

(b) HTFB-14

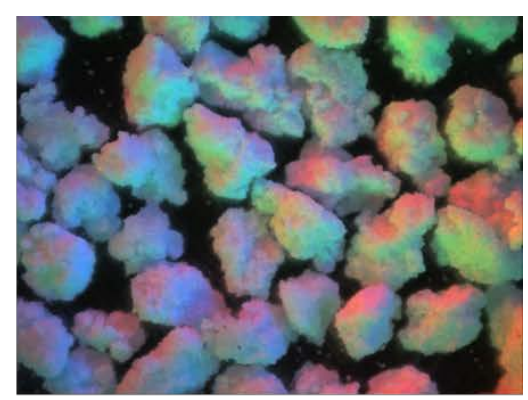

(c) SSPW-15

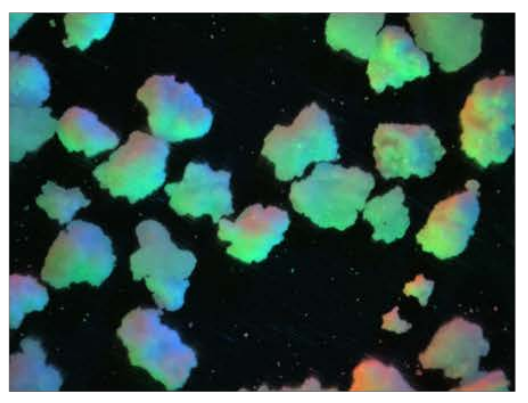

506

507

Fig. 10: Images showing the shape and structure of the granules from different batches produced using different impellers. 


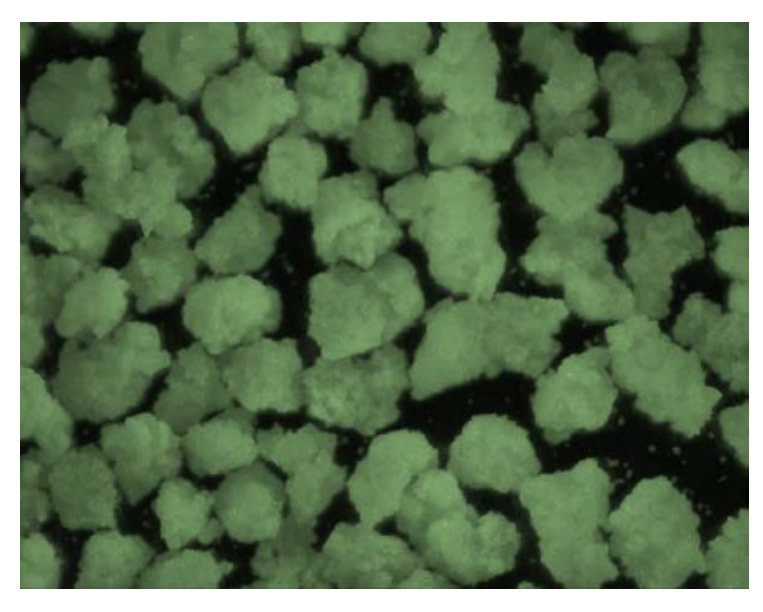

$0.71 \mathrm{~mm}$

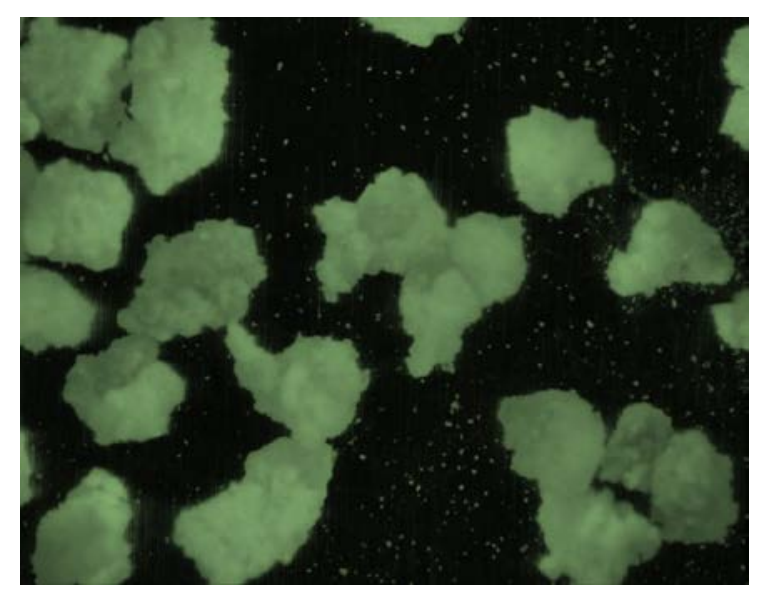

$2.0 \mathrm{~mm}$

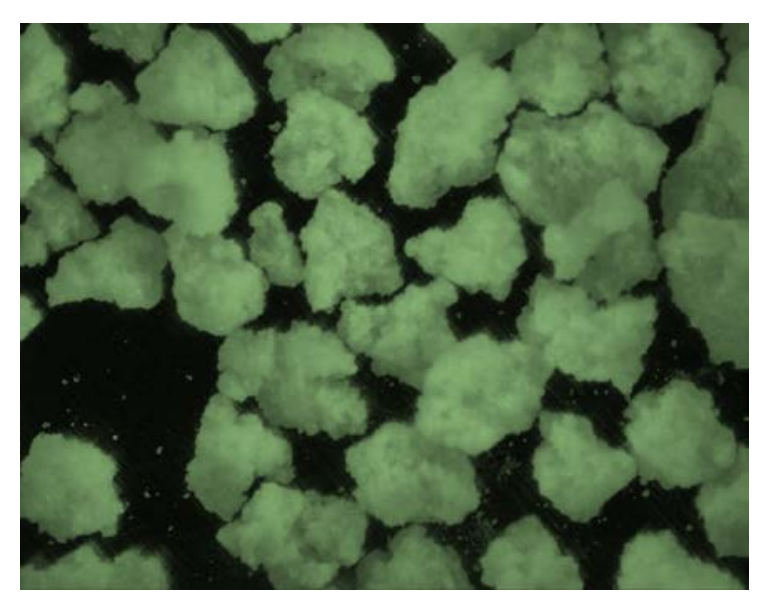

$1.0 \mathrm{~mm}$

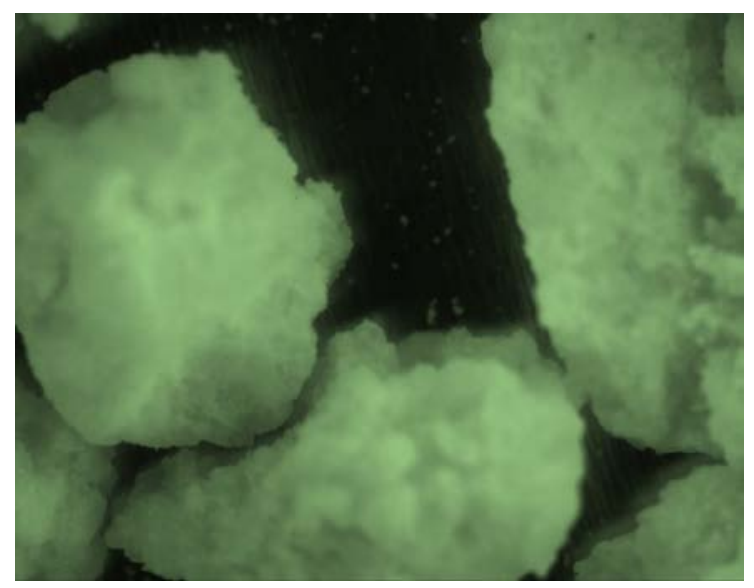

$3.35 \mathrm{~mm}$

510 Fig. 11: Images showing the shape and structure of the granules of different sizes from the same batch 


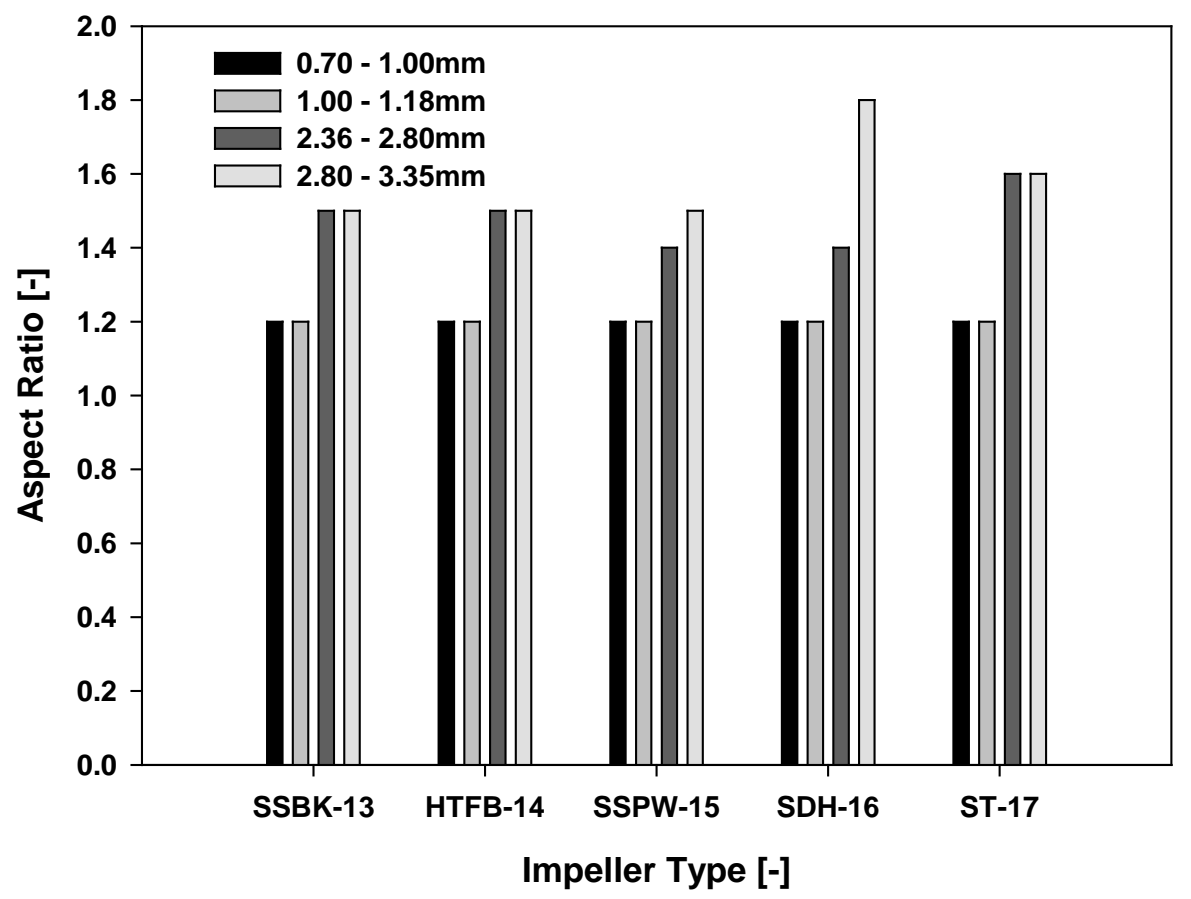

Fig. 12: Effect of impeller design on the aspect ratio of granules of different sizes. 